\title{
Reform of Justice's a Natural Gas Regulation in Indonesia
}

\author{
Tantri Yanti Muhamad \\ Student at Doctoral Program of Law \\ Universitas Borobudur \\ Jakarta, Indonesia \\ tantriyantimuhamad@gmail.com
}

\author{
Faisal Santiago \\ Universitas Borobudur \\ Faculty of Law \\ Jakarta, Indonesia \\ faizalsantiago@borobudur.ac.id
}

\begin{abstract}
Abstract of this paper aims to analyze the Regulation of Law no. 22 of 2001 on Oil and Gas (Oil and Gas Law) becomes a new round in regulation of oil and gas regulation in Indonesia. This oil and gas law wishes to emphasize that Indonesia's national development should be directed towards the realization of people's prosperity and prosperity. This study found that in the Oil and Gas Law has been affirmed about the purpose of natural gas management in order to increase state revenues, create jobs, improve prosperity and prosperity of the people fairly and equitably, and keep the environment sustainability. Natural gas management must be done carefully and carefully for the achievement of social welfare and justice for all Indonesian people. Several decisions of the Constitutional Court have canceled the articles in the Oil and Gas Law, the changes in the law and regulation in the field of oil and gas, especially natural gas is very important and urgent, to ensure the existence of laws that create happiness and justice for all people. This thesis has 2 (two) problem formulation. First, What is the purpose of natural gas management in Indonesia. Two, How is the regulation of natural gas reform in Indonesia. The research method used to solve the above problems is the normative research method (literature study) conducted by studying and reading scientific books, newspapers, seminar results papers, laws and regulations related to the issues discussed. Hopefully this thesis is useful for the progress of development in Indonesia.
\end{abstract}

Keywords—reform, gas regulation, justice.

\section{INTRODUCTION}

Since the enactment of Law no. 22 of 2001 on Oil and Natural Gas dated November 23, 2001, is a new phase in the regulation of oil and gas regulation in Indonesia. With various national and international developments, the amendment of the law is done in order to create an oil and gas business activity that is self-reliant, reliable, transparent, competitive, efficient, environmentally friendly, and encourages the development of national potential and role. With such considerations, it is expected that the birth of the law will answer the welfare for the community.

Basically, all natural resources must be used for the greatest prosperity of the people. Management must also answer the concept of social justice. Some considerations in this law, among others: First, national development should be directed to the realization of people's welfare by carrying out reforms in all areas of national life and state based on
Pancasila and the UUD NRI Tahun 1945. Second, oil and natural gas is a natural resource strategic non-renewable controlled by the state and is a vital commodity that controls the livelihood of the people and has an important role in the national economy so that its management must be able to maximally provide prosperity and prosperity of the people. Third, oil and gas business activities have an important role in providing significant added value to the national economic growth that is increasing and sustainable.

One of the areas related to the expectation of the concept is oil and gas governance. The government has various policies regarding the management of natural gas. In this case, the policy of natural gas management is intended to encourage national gas energy security. One of the policies issued by the government is unbundling (segregation of commercial and transportation business) and open access (utilization of joint pipeline) of downstream gas business.

\section{RESEARCH METHODS}

This research will be compiled using normative juridical research type, that is research which focused to study the application of positive law principles. Normative juridical is an approach that uses positivist legit conception. This study uses the approach of legislation and doctrine of experts and books that have relevance to the problem.

\section{PROBLEM FORMULATION}

From the background of the above problems, the authors are interested to examine by taking the following problems:

1. What is the purpose of natural gas management in Indonesia?

2. How is the regulation of natural gas reform in Indonesia?

\section{DISCUSSION}

\section{A. The Purpose of Natural Gas Management in Indonesia}

There are several important principles in Law Number 22 Year 2001 regarding Oil and Natural Gas, namely people economy, integrity, benefits, justice, equity, equity, common prosperity and prosperity of the people, security, safety, and legal certainty and environmental insight. The law stipulates that the operation of Oil and Gas business activities is aimed at:

a. Ensuring effective and efficient implementation of and control of the business activities of Exploration and 
Exploitation in a state-of-the-art, sustainable and competitive manner over state-owned and strategic nonrenewable Oil and Gas through an open and transparent mechanism;

b. Ensuring the effectiveness of the implementation of the controlled processing, transport, storage and trade businesses carried out through fair, healthy and transparent business competition mechanisms;

c. Ensure the efficiency and effectiveness of the availability of petroleum and natural gas, both as energy source and as raw material, for domestic needs;

d. Support and develop national capabilities to be more competitive in national, regional and international level;

e. Increase state revenues to contribute enormously to the national economy and develop and strengthen Indonesia's trade and industry position;

f. Creating employment, improving the welfare and prosperity of the people are just and equitable, and still maintain the environment.

There have been changes, including in relation to the Constitutional Court's Decision on 13 November 2012, which canceled the Implementing Agency for oil and gas management. The affirmation of the law is the realization that oil and natural gas as the unmatched strategic natural resources contained within the Indonesian Legal Mining Territory is a national asset controlled by the state, administered by the Government as the holder of the Mining Authority. The Government as the holder of Mining Authority shall establish an Implementing Body. Well, this body is then by the Constitutional Court dissolved, because it is considered the concept of control by the state authorized to the agency is contrary to the principle of the constitution.

In connection with open access, generally regulated in Article 8, among others, provides that the Government gives priority to the utilization of natural gas for domestic needs and is tasked with providing strategic reserves of Petroleum to support the provision of domestic Fuel Oil. The Government shall ensure the availability and smooth distribution of Fuel Oil which is a vital commodity and affect the livelihood of the people throughout the territory of the Unitary State of the Republic of Indonesia.

Specifically, Article 8 paragraph (3), affirms the business activities of the Natural Gas Transportation through pipes concerning the public interest, its operation is arranged so that its utilization is open to all users. The Government must implement the concept after Government Regulation Number 36 Year 2004 regarding Oil and Gas Downstream Business Activity is issued.

The phrase "public interest" referred to in Article 8 paragraph (3), including the interests of producers, consumers' interests, and other communities associated with the activities of natural gas transportation.

In Article 31 of Government Regulation Number 36 Year 2004 concerning Oil and Gas Downstream Business Activity mentioned:

a) Business entities shall provide an opportunity for other parties to jointly utilize facilities and means of transportation of natural gas through its pipeline with consideration of technical and economic aspects;

b) In the event of a scarcity of fuel oil, and in remote areas, in order to reduce the cost of distribution, the Enterprise shall provide an opportunity for other parties to jointly utilize the facilities and transportation facilities it possesses with consideration of technical and economic aspects;

c) The joint use of facilities and transportation facilities as referred to in paragraphs (1) and (2) is established, regulated and supervised further by the Regulatory Body with due regard to technical and economic aspects.

In the Elucidation of Article 31 Paragraph (1) it is mentioned that technical consideration is that to the gas transportation facility through pipeline having more capacity can be utilized to other party without disturbing operational activity of facility owner. Meanwhile, economic consideration is that other parties who will utilize gas transportation facilities through the pipeline must consider the economic interests of the facility owner, among others, concerning the rate of return of investment (rate of return).

More concretely, the provisions are then regulated in the Minister of Energy and Mineral Resources Regulation No. 19 of 2009 on Gas Gas Business Activities through Pipes. This regulatory consideration is in order to increase the utilization of natural gas for domestic needs and to improve the development of natural gas infrastructure through a capital-intensive and high-risk pipeline and to create a healthy investment climate as well as guarantee the return on investment for business entities in the natural gas pipeline business.

In Article 9 of the Ministerial Regulation, it is stated "in the conduct of the Gas Trade Business Activities through the Pipe of Business Entity as referred to in Article 6, shall use Transmission and / or Distribution Pipes available to be able to be used together (open access) on Transmission and / or Distributed Network Area Distribution ". Article 6 determines: "(1) Natural Gas Business Activities through Pipeline shall be carried out by the Business Entity after obtaining Gas Trading Business License through Pipe; (2) The Natural Gas Trading Business Activities through Piping as referred to in paragraph (1) shall be carried out in certain Commercial Areas; (3) Certain Commercial Areas as referred to in paragraph (2) have geographical coordinate boundaries similar to Distribution Network Areas ".

While Article 13 provides: "(1) Excluded from the provisions referred to in Article 12, in the framework of efficiency and optimizing the utilization and fulfillment of domestic Gas requirements, the Director General may require Business License Holders of Natural Gas Business License through Dedicated Downstream Pipes for utilization along with facilities owned by other parties. (2) The joint use by the Business Entity as referred to in paragraph (1) shall be carried out after receiving consideration from the Regulatory Body. (3) In the event that a Business Entity carries out the joint utilization of the Dedicated Downstream Pipeline facility as referred to in paragraph (I) to a Business Entity is obliged to have a Gas Transportation Business License Through Pipeline. "Article 12 referred to:" Business Entity holder of Commercial Gas Business License The Earth Through Downstream Dedicated Pipes and Special Rights as referred to in Article 11 shall be prohibited from conducting Gas Transportation Business Activities through Pipes on Dedicated Pipes Downstream. "Whereas Article 11:

1) To obtain License of Natural Gas Trading Business through Dedicated Pipeline Downstream, Business 
Entity shall submit application to Minister through Director General with copy to Regulator Body by enclosing:

a) Initial agreement with producers / suppliers of Natural Gas indicated by the Head of Agreement (HoA) or Memorandum of Understanding (MoU);

b) Initial agreement with prospective Gas Consumers indicated by the Head of Agreement (HoA) or Memorandum of Understanding (MoU);

c) The results of technical and economical studies which include, among other things, the pipeline, length, capacity and pipeline development plans as well as the number of Natural Gas Consumers and sales volume of Natural Gas;

d) A written statement on stamp duty that the Downstream Dedicated Pipes constructed shall be used solely for the distribution of Natural Gas;

e) Administrative and technical requirements in accordance with the provisions of legislation.

2) In case the application is complete and correct, the Director General shall conduct evaluation within a period of no more than 3 (three) months upon the application as referred to in paragraph (1).

3) Based on the evaluation of the application as referred to in paragraph (2), the Director General on behalf of the Minister shall approve or reject the application of the Business Entity.

4) If the application as meant in paragraph (3) is approved, the Director General on behalf of the Minister shall grant the License of Natural Gas Business via Dedicated Pipe Downstream.

5) Business Entities that have obtained License of Natural Gas Business via Dedicated Pipeline Downstream shall be entitled to Special Rights from the Regulatory Body.

6) Against Downstream Dedicated Piping as referred to in paragraph (4) shall be further stipulated in the National Transmission and Distribution Gas Transmission Plans $"$.

\section{B. Reform of natural gas regulations in Indonesia}

These conditions should be the state's concern to initiate a better law. Where the concept of development is inseparable from the existence of the state. In general, the purpose of the establishment of a state is to create happiness for its people. As the Preamble of the UUD NRI Tahun 1945 , the purpose of the Indonesian state is to protect the whole of Indonesia's blood sphere, to promote the common prosperity, to improve the life of the nation, and to carry out the world order.

Based on Article 1 of the UUD NRI Tahun 1945, the form of the Indonesian state is unity. According to Mahfud $\mathrm{MD}$, the concept of a unitary state is a constitutional concept governing the relationship of central and regional power. Pursuant to Article 18B paragraph (1) of the UUD NRI Tahun 1945, it is affirmed that the state recognizes and respects special regional or special government units regulated by law. The provision asserts, Indonesia is a unitary state, in addition to implementing the principle of autonomy, also implement the principle of special autonomy and special autonomy. Such a concept is, in fact, derived from what is called the idea of unity.
One thing that becomes an important emphasis on the idea of unity in the concept of the Indonesian state based on Pancasila is the goal as the Preamble of the UUD NRI Tahun 1945, ultimately to achieve the human happiness of Indonesia in the birth and the mind. With such a concept, then the achievement of human happiness can not be separated also by the development of the law. The term "legal reform", "law change", "legal counseling", "legal reform", and "legal modernization" are widely known. Satjipto Rahardjo, uses the term "legal reform". Soetandyo Wignjosoebroto distinguishes the concept of legal reform in the sense of legal reform (law only as a subsystem and serves as a tool of social enginering alone) with law reform (law not only law enforcement affairs, but also public affairs).

Legal development is part of a series of national development, whose ultimate objective is to refer to the objectives of the state, as affirmed in the Preamble to the UUD NRI Tahun 1945. Directly or not, the concept of legal development can not possibly be released from the concept of legal politics. Etymologically, the term "legal politics" is derived from the Dutch term, "Rechtspolitiek", the formation of the word "rechts" (meaning law) and "politic" (meaning belied or policy). Theoretically, legal and political relations are seen in three relationship models: (1) the determinant law of politics because every political agenda must be subject to the rule of law (das sollen); (2) the political determinant of the law because in fact that law is a political product so that any law before us is nothing but crystallization from competing political wills (das sein); (3) law and politics are interdeterminant because politics without law will be unjust, while law without political guard will be paralyzed.

Prof. Mahfud MD emphasized that the politics of the law should be based on the purpose of the state and the prevailing legal system, which in the context of Indonesia, the system is contained in the Preamble of the UUD NRI Tahun 1945, especially Pancasila, which gave birth to the rules of law. By Prof. Muliadi explained, legal politics can be understood from the existing sentence, as far as the sentence is clear and not debated. If there is a debate, then the legal politics can be searched from the historical background of the emergence of the idea of the formation of legislation, what the lawmakers want about it.

Development of this law is very important, especially related to a number of articles that have been improved through the Constitutional Court Decision (MK). There are two Constitutional Court Decisions directly related, namely Decision of the Constitutional Court. 36 / PUU-X / 2012 and Decision of the Constitutional Court. 002 / PUU-I / 2003. Through Decision No. MK. 36 / PUU-X / 2012 (November 13, 2013), the Constitutional Court straightens a number of articles, namely Article 1 point 23, Article 4 paragraph (3), Article 11 paragraph (1), Article 20 paragraph (3), Article 21 paragraph ( 1), Article 41 Paragraph (2), Article 44, Article 45, Article 48 (1), Article 49, Article 59 Sub-Article a, Article 61 and Article 63. 002 / PUU-I / 2003 (December 21, 2004), rectifies Article 12 paragraph (3), Article 22 paragraph (1), and Article 28 paragraph (2) and paragraph (3).

A number of these articles are decided contrary to the UUD NRI Tahun 1945. There is one important point in this 
context, which concerns the economic orientation associated with the development that will be implemented. Philosophically, Article 33 of the UUD NRI Tahun 1945 of the Republic of Indonesia became the foundation for the development of Indonesian economic law, which is directly oriented to the concept of a just economy and sustainability. The concept becomes a patron in giving the state direction through government from the potential for failure to exercise power from the limitations of its authority. Applicatively, the economic concept has a noble purpose, among others, the realization and improvement of welfare for all the people of Indonesia, which is held must be seen as a planned, programmed, systematic and sustainable effort in order to improve the welfare and quality of life of all citizens. One form of the process of achievement is done through the development of a more justice law.

\section{CONCLUSIONS}

Based on the above discussion, the writer can conclude as follows: First, basically the purpose of natural gas management is to ensure the effectiveness of the implementation and control of business activities, and to support and foster the national capability of Indonesia to be more competitive in national, regional and global. Another goal is to increase state revenues and create jobs, improve the welfare and prosperity of the people in a fair and equitable way, while maintaining environmental sustainability. Second, the concept of natural gas management must be done carefully for the achievement of people's welfare. A number of Constitutional Court Decisions which have canceled the articles in the Oil and Natural Gas Law have consequences to make regulatory reform related to natural gas is very urgent to do. Nevertheless, the process should ensure the existence of a law that creates happiness and prosperity for its people, as the Preamble of the UUD NRI Year 1945, the goal of the Indonesian state is to protect the whole of Indonesia's blood, to promote the common good, to educate the nation and to carry out the world order.

\section{REFERENCES}

[1] Arief Hidayat, "Negara Hukum Pancasila, Model Ideal Penyelenggaraan Negara Hukum”, Makalah Semiloka Pancasila dan Konstitusi Tahun 2011, Mahkamah Konstitusi, Jakarta, 2011.

[2] Arief Muliadi, Politik Hukum, Cetakan Ke-1, Akademia Permata, Padang, 2013.

[3] Astim Riyanto, Negara Kesatuan: Konsep, Asas, dan Aktualisasinya, Yapemdo, Bandung, 2010.

[4] Miriam Budiardjo, Dasar-dasar Ilmu Politik Hukum, Gramedia, Jakarta, 2004.

[5] Moh Mahfud MD, , Membangun Politik Hukum Menegakkan Konstitusi, Third Print, Rajawali Press, Jakarta, 2012.

[6] , Politik Hukum di Indonesia, Cet. Ke-5, Rajawali Press, Jakarta, 2012.

[7] Konstitusi dan Hukum dalam Kontroversi Isu, Rajawali Press, Jakarta, 2010.

[8] Satjipto Rahardjo, Negara Hukum yang Membahagiakan Rakyatnya, Genta Press, Yogyakarta, 2006.

[9] Wignjosoebroto, Soetandyo, "Pembaruan Hukum Masyarakat Indonesia Baru", in Donny Donardono dkk, Wacana Pembaharuan Hukum di Indonesia, HuMa, Jakarta, 2007,

[10] Decision Constituonal Court No. 002 / PUU-I / 2003.

[11] Decision Constituonal Court No. 36 / PUU-X / 2012

[12] Legislation:

[13] Indonesia, UUD NRI Tahun 1945

[14] _L_Law No.. 22 of 2001 on Oil and Gas

[15] ___ Government Regulation Number 36 Year 2004 concerning Oil and Gas Downstream Business Activity 